\title{
Transfer of Bacillus halodenitrificans Denariaz et al. 1989 to the genus Virgibacillus as Virgibacillus halodenitrificans comb. nov.
}

Correspondence Jung-Hoon Yoon jhyoon@kribb.re.kr

\author{
Jung-Hoon Yoon, ${ }^{1}$ Tae-Kwang $\mathrm{Oh}^{1}$ and Yong-Ha Park ${ }^{1,2}$ \\ ${ }^{1}$ Korea Research Institute of Bioscience and Biotechnology (KRIBB), PO Box 115, Yusong, \\ Taejon, Korea \\ ${ }^{2}$ National Research Laboratory of Molecular Ecosystematics, Institute of Probionic, Probionic \\ Corporation, Bio-venture Center, Korea Research Institute of Bioscience and Biotechnology \\ (KRIBB), PO Box 115, Yusong, Taejon, Korea
}

\begin{abstract}
A Gram-variable, endospore-forming moderately halophilic rod, strain SF-121, was isolated from a marine solar saltern of the Yellow Sea in Korea. The result of 16S rRNA gene sequence analysis showed that strain SF-121 has highest sequence similarity (99.7\%) with the type strain of Bacillus halodenitrificans. Phylogenetic analyses based on 16S rRNA gene sequences revealed that $B$. halodenitrificans DSM $10037^{\top}$ and strain SF-121 are more closely related to the genus Virgibacillus than to the genus Bacillus. Strain SF-121 and B. halodenitrificans DSM $10037^{\top}$ exhibited 16S rRNA gene similarity levels of $95 \cdot 3-97 \cdot 5 \%$ with the type strains of Virgibacillus species and $94.0 \%$ with the type strain of Bacillus subtilis. DNA-DNA relatedness and phenotypic data indicated that $B$. halodenitrificans DSM $10037^{\top}$ and strain SF-121 are members of the same species. B. halodenitrificans DSM $10037^{\top}$ and strain SF-121 exhibited DNA-DNA relatedness values of 9-11\% with the type strains of Virgibacillus carmonensis and Virgibacillus marismortui. On the basis of the phenotypic, chemotaxonomic, phylogenetic and genetic data, $B$. halodenitrificans should be reclassified in the genus Virgibacillus as Virgibacillus halodenitrificans comb. nov.
\end{abstract}

Innovations in the study of bacterial systematics have aided the reclassification of some bacilli into newly described genera or other related genera (Wisotzkey et al., 1992; Ash et al., 1993; Shida et al., 1996; Heyndrickx et al., 1998; Wainø et al., 1999; Yoon et al., 2001). The genus Virgibacillus was first proposed by Heyndrickx et al. (1998) for Bacillus pantothenticus. Subsequently, a second species, Virgibacillus proomii, was included in the genus (Heyndrickx et al., 1999). The genus Salibacillus was proposed for a single species assigned to the genus Bacillus, Bacillus salexigens (Wainø et al., 1999), and Bacillus marismortui was later transferred to the genus Salibacillus (Arahal et al., 2000). However, Heyrman et al. (2003) proposed to combine the two genera Virgibacillus and Salibacillus in a single genus. According to the Rules of the Bacteriological Code, the two Salibacillus species were transferred to the genus Virgibacillus. In addition, Heyrman et al. (2003) proposed three novel Virgibacillus species, Virgibacillus carmonensis, Virgibacillus

Published online ahead of print on 17 September 2004 as DOI 10.1099/ijs.0.63196-0.

The GenBank/EMBL/DDBJ accession numbers for the 16S rRNA gene sequences of strain SF-121 and Bacillus halodenitrificans DSM $10037^{\top}$ are AY543168 and AY543169, respectively. necropolis and Virgibacillus picturae. The genus Virgibacillus comprises these seven species with validly described names at the time of writing. Recently, a moderately halophilic bacterial strain, SF-121, was isolated from a marine solar saltern of the Yellow Sea in Korea. This organism was found to have closest phylogenetic affiliation to Bacillus halodenitrificans from the results of $16 \mathrm{~S}$ rRNA gene sequence analysis. However, strain SF-121 and B. halodenitrificans were found to be phylogenetically more closely related to the genus Virgibacillus than to the genus Bacillus. Accordingly, the aim of the present study was to establish the exact taxonomic positions of strain SF-121 and B. halodenitrificans using a combination of phenotypic properties, phylogenetic analysis based on $16 \mathrm{~S}$ rRNA gene sequences and genotypic relatedness.

Strain SF-121 was isolated by the usual dilution plating technique on marine agar 2216 (MA; Difco) at $30^{\circ} \mathrm{C}$. B. halodenitrificans DSM $10037^{\mathrm{T}}$, Virgibacillus marismortui DSM $12325^{\mathrm{T}}$ and $V$. carmonensis DSM $14868^{\mathrm{T}}$ were obtained from the Deutsche Sammlung von Mikroorganismen und Zellkulturen (DSMZ), Braunschweig, Germany. Cell morphology was examined by light microscopy (Nikon E600) and transmission electron microscopy. Flagellum type was examined by transmission electron 
microscopy using cells from exponentially growing cultures. Gram reaction was determined using the bioMérieux Gram Stain kit according to the manufacturer's instructions. Growth under anaerobic conditions was determined after incubation in an anaerobic chamber on MA and MA supplemented with nitrate that had been prepared anaerobically. The $\mathrm{pH}$ range for growth was determined in marine broth (MB; Difco) adjusted to $\mathrm{pH}$ values $4 \cdot 5,5 \cdot 0,5 \cdot 5,6 \cdot 0,6 \cdot 5,7 \cdot 0$, $7 \cdot 5,8 \cdot 0,8 \cdot 5,9 \cdot 0$ and $9 \cdot 5$. Growth at various $\mathrm{NaCl}$ concentrations was investigated in $\mathrm{MB}$ or trypticase soy broth (Difco). Growth in the absence of $\mathrm{NaCl}$ was investigated in trypticase soy broth without $\mathrm{NaCl}$. Growth at various temperatures $\left(4-50{ }^{\circ} \mathrm{C}\right)$ was measured on MA. Oxidase activity was determined by oxidation of $1 \% p$-aminodimethylaniline oxalate. Catalase activity was determined by bubble production in a $3 \%(\mathrm{v} / \mathrm{v})$ hydrogen peroxide solution. Hydrolysis of aesculin, Voges-Proskauer and methyl red reactions and nitrate reduction were determined as described by Lanyi (1987). Hydrolysis of casein, starch and Tween 80 and urease activity were determined as described by Cowan \& Steel (1965). Hydrolysis of hypoxanthine, tyrosine and xanthine was examined on MA with the substrate concentrations described previously (Cowan \& Steel, 1965). The API ZYM system (bioMérieux) was used to determine enzyme activity. Acid production from carbohydrates was determined as described by Leifson (1963). Utilization of substrates as sole carbon and energy sources was tested according to the method of Baumann \& Baumann (1981) supplemented with $2 \%$ (v/v) Hutner's mineral base (Cohen-Bazire et al., 1957) and $1 \%(\mathrm{v} / \mathrm{v})$ vitamin solution (Staley, 1968).

Cell mass for analysis of the cell wall, menaquinones and polar lipids and for DNA extraction was produced in MB at $37^{\circ} \mathrm{C}$. For fatty acid methyl ester analysis, cell mass of strain SF-121 and B. halodenitrificans DSM $10037^{\mathrm{T}}$ was obtained from agar plates after cultivation for 2 days at $37^{\circ} \mathrm{C}$ on MA. The isomer type of diaminopimelic acid in the peptidoglycan was determined by the method described by Komagata \& Suzuki (1987). Menaquinones were analysed as described previously (Komagata \& Suzuki, 1987) using reverse-phase HPLC. Polar lipids were extracted using the procedures described by Minnikin et al. (1984) and identified by twodimensional TLC followed by spraying with appropriate detection reagents (Komagata \& Suzuki, 1987). For quantitative analysis of cellular fatty acid compositions, a loop of cell mass was harvested and fatty acid methyl esters were extracted and prepared according to the standard protocol of the MIDI/Hewlett Packard Microbial Identification System (Sasser, 1990). Chromosomal DNA was isolated and purified according to the method described previously (Yoon et al., 1996), with the exception that ribonuclease T1 was used together with ribonuclease A. The DNA G+C content was determined by the method of Tamaoka \& Komagata (1984) with the modification that DNA was hydrolysed and the resultant nucleotides were analysed by reverse-phase HPLC. The 16S rRNA gene was amplified by PCR using two universal primers as described previously
(Yoon et al., 1998). The PCR product was purified with a QIAquick PCR Purification kit (Qiagen). Sequencing of the amplified 16S rRNA gene and phylogenetic analysis were performed as described previously (Yoon et al., 2003). DNA-DNA hybridization was performed fluorometrically by the method of Ezaki et al. (1989) using photobiotinlabelled DNA probes and microdilution wells. Hybridization was performed with five replications for each sample. The highest and lowest values obtained in each sample were excluded and the mean of the remaining three values was taken as the relatedness value.

Strain SF-121 was a Gram-variable rod, approximately $0 \cdot 6-0 \cdot 8 \times 2 \cdot 0-4 \cdot 0 \mu \mathrm{m}$ after cultivation for 3 days at $37^{\circ} \mathrm{C}$ on MA. It was motile by means of a single polar flagellum. Terminal or subterminal ellipsoidal spores were observed in swollen sporangia. Colonies of strain SF-121 were circular to irregular, raised, translucent, cream in colour and 2-3 mm after incubation for 3 days at $37^{\circ} \mathrm{C}$ on MA. It grew at 10 and $45^{\circ} \mathrm{C}$ with an optimum temperature of $35-40^{\circ} \mathrm{C}$; it did not grow at 4 or $50^{\circ} \mathrm{C}$. Optimal growth was at $\mathrm{pH} 7 \cdot 5$; it grew at $\mathrm{pH} 5.0$ but not at $\mathrm{pH} 4 \cdot 5$. Strain SF-121 grew in the presence of $0-23 \% \mathrm{NaCl}$ with an optimum of $2-7 \% \mathrm{NaCl}$. It grew anaerobically on MA only when nitrate was present. Strain SF-121 showed catalase and oxidase activities but no urease activity. Hypoxanthine, starch, Tween 80, tyrosine and xanthine were not hydrolysed. It reduced nitrate to nitrite. Strain SF-121 contained meso-diaminopimelic acid as the diagnostic diamino acid in the cell-wall peptidoglycan. The predominant menaquinone found in strain SF-121 was menaquinone-7 (MK-7). Strain SF-121 had a cellular fatty acid profile that consisted mostly of branched fatty acids; the major fatty acids were anteiso- $\mathrm{C}_{15: 0}(54 \cdot 1 \%)$ and anteiso- $\mathrm{C}_{17: 0}(32 \cdot 0 \%)$. This profile was most similar to that of B. halodenitrificans DSM $10037^{\mathrm{T}}$; the major fatty acids detected in B. halodenitrificans DSM $10037^{\mathrm{T}}$ were anteiso$\mathrm{C}_{15: 0}(56 \cdot 3 \%)$, anteiso- $\mathrm{C}_{17: 0}(25 \cdot 5 \%)$ and iso- $\mathrm{C}_{16: 0}$ $(8 \cdot 7 \%)$. The cellular polar lipids found in strain SF-121 were phosphatidylglycerol and diphosphatidylglycerol. The DNA G + C content of strain SF-121 was $39 \mathrm{~mol} \%$. Other phenotypic characteristics are shown in Table 1 or are given in the species description below.

The 16S rRNA gene sequences of strain SF-121 and $B$. halodenitrificans DSM $10037^{\mathrm{T}}$ determined in this study comprised $1521 \mathrm{nt}$, approximately $96 \%$ of the Escherichia coli $16 \mathrm{~S}$ rRNA gene sequence. The 16S rRNA gene sequences of strain SF-121 and B. halodenitrificans DSM $10037^{\mathrm{T}}$ were $99.7 \%$ similar (5 nt differences). The phylogenetic tree based on the neighbour-joining algorithm showed that strain SF-121 and B. halodenitrificans DSM $10037^{\mathrm{T}}$ fell within the radiation of the cluster comprising Virgibacillus species, not Bacillus species (Fig. 1). Similar tree topology was also found in the tree generated by maximum parsimony (data not shown). Strain SF-121 and B. halodenitrificans DSM $10037^{\mathrm{T}}$ exhibited highest $16 \mathrm{~S}$ rRNA gene similarity values $(97 \cdot 2-97 \cdot 5 \%)$ with the type strains of $V$. carmonensis and V. marismortui, and 16S rRNA gene 
Table 1. Phenotypic characteristics of Virgibacillus species and B. halodenitrificans

1, Virgibacillus pantothenticus; 2, V. proomii; 3, Virgibacillus salexigens; 4, V. marismortui; 5, V. carmonensis; 6, V. necropolis; 7, V. picturae; 8, B. halodenitrificans. +, Positive; -, negative; W, weakly positive; V, variable; ND, not determined. Data in columns 1-7 are from Arahal et al. (1999, 2000), Heyndrickx et al. (1999), Wainø et al. (1999) and Heyrman et al. (2003). Data in parentheses are for the type strain. All species are rods, motile, positive for catalase and negative for growth on D-arabinose and D-xylose.

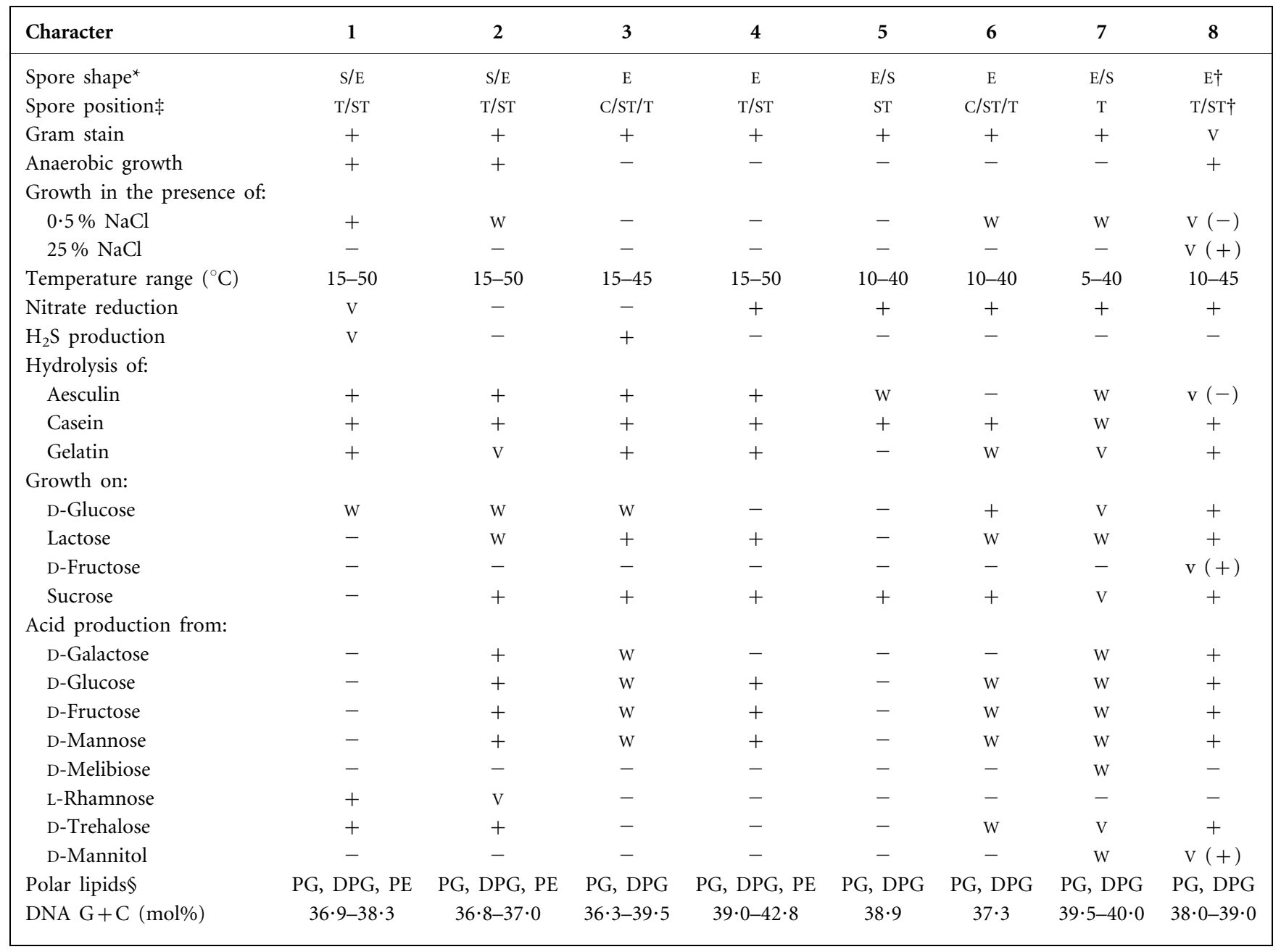

${ }^{\star}$ E, Ellipsoidal; s, spherical.

$\dagger$ Data for strain SF-121.

‡, Central; ST, subterminal; T, terminal.

§DPG, Diphosphatidylglycerol; PE, phosphatidylethanolamine; PG, phosphatidylglycerol.

similarity values of $95 \cdot 3-96 \cdot 7 \%$ with the type strains of other Virgibacillus species. Levels of $16 \mathrm{~S}$ rRNA gene similarity between strain SF-121 and B. halodenitrificans DSM $10037^{\mathrm{T}}$ and other species used in the phylogenetic analysis were lower than $95 \cdot 3 \%$.

Strain SF-121 and B. halodenitrificans were found to have similar phenotypic properties (Table 1). The mean value of DNA-DNA relatedness between strain SF-121 and $B$. halodenitrificans DSM $10037^{\mathrm{T}}$ was $87 \%$ when their DNA was used individually as a labelled DNA probe for crosshybridization. This value indicated that they are members of the same genomic species (Wayne et al., 1987). Phylogenetic analyses based on $16 \mathrm{~S}$ rRNA gene sequences indicated that $B$. halodenitrificans is more phylogenetically affiliated to the genus Virgibacillus than to the genus Bacillus (Fig. 1). The predominant menaquinone and fatty acid profiles of $B$. halodenitrificans were similar to those of the genus Virgibacillus, although there are few clear-cut differences in chemotaxonomic characteristics between the genera Bacillus and Virgibacillus (Spring et al., 1996; Wainø et al., 1999; Yoon et al., 2002; Heyrman et al., 2003). B. halodenitrificans is also phylogenetically related to the genera Lentibacillus and Oceanobacillus. However, B. halodenitrificans and the genus Virgibacillus are clearly differentiated from the genus Lentibacillus by differences in fatty acid 


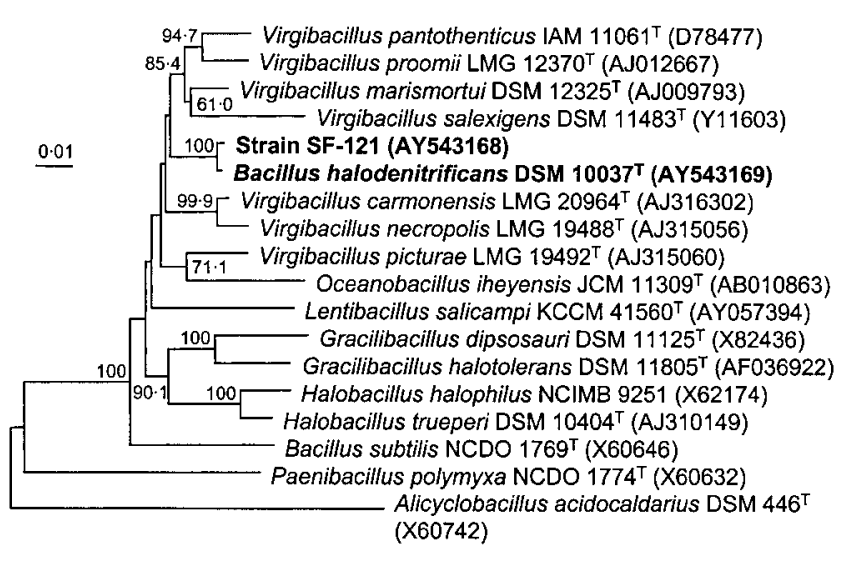

Fig. 1. Neighbour-joining tree based on 16S rRNA gene sequence data showing the phylogenetic positions of $B$. halodenitrificans DSM $10037^{\top}$ and strain SF-121, Virgibacillus species and some other related taxa. Bootstrap values (1000 replications) are shown as percentages at each node only if they are $50 \%$ or greater. Bar, 0.01 substitutions per nucleotide position.

profiles, particularly in the proportion of the fatty acid iso$\mathrm{C}_{16: 0}$ (Yoon et al., 2002; Heyrman et al., 2003). In the neighbour-joining phylogenetic tree, the genus Oceanobacillus joined the type strain of $V$. picturae (Fig. 1). There are not enough phenotypic, particularly chemotaxonomic, differences between Virgibacillus and Oceanobacillus (Lu et al., 2001; Heyrman et al., 2003). Accordingly, the taxonomic relationship between Virgibacillus and Oceanobacillus may have to be re-evaluated. Both phylogenetic and phenotypic data indicated that $B$. halodenitrificans is a member of the genus Virgibacillus rather than the genus Bacillus. B. halodenitrificans DSM $10037^{\mathrm{T}}$ and strain SF-121 were differentiated from the type strains of $V$. carmonensis and $V$. marismortui by DNA-DNA relatedness values of 9-11\% and from other Virgibacillus species by 16S rRNA gene similarity levels of $<96.7 \%$ (Wayne et al., 1987; Stackebrandt \& Goebel, 1994). B. halodenitrificans was also differentiated from other Virgibacillus species by some phenotypic properties (Table 1). Therefore, on the basis of the data presented, it is proposed that $B$. halodenitrificans Denariaz et al. 1989 be transferred to the genus Virgibacillus as Virgibacillus halodenitrificans comb. nov.

\section{Description of Virgibacillus halodenitrificans (Denariaz et al. 1989) comb. nov.}

Virgibacillus halodenitrificans [ha.lo.de.ni.tri'fi.cans. Gr. n. hals salt; L. v. denitrifico to denitrify; N.L. part. adj. halodenitrificans salt (-requiring) denitrifying].

Basonym: Bacillus halodenitrificans Denariaz et al. 1989.

Cells are rods, $0 \cdot 6-0 \cdot 8 \times 2 \cdot 5-4 \cdot 0 \mu \mathrm{m}$. Gram variable. Motile by means of single or peritrichous flagella. Terminal or subterminal ellipsoidal spores are observed in swollen sporangia (observed only in strain SF-121). Colonies are circular to slightly irregular, raised, translucent, cream coloured and $2-3 \mathrm{~mm}$ after incubation for 3 days on MA. Growth occurs between 10 and $45^{\circ} \mathrm{C}$ with an optimum of $35-40{ }^{\circ} \mathrm{C}\left(38^{\circ} \mathrm{C}\right.$ for the type strain). Optimal pH for growth is around $\mathrm{pH} 7 \cdot 4-7 \cdot 5$. The $\mathrm{pH}$ range for growth is between $5 \cdot 8$ and $9 \cdot 6$ (for the type strain). Growth occurs in the presence of $2-23 \% \mathrm{NaCl}(2-25 \%$ for the type strain); optimal growth occurs in the presence of $3-7 \% \mathrm{NaCl}$. Growth occurs under anaerobic conditions on MA only in the presence of nitrate. Oxidase positive. Urease negative. Starch, Tween 80 and tyrosine are not hydrolysed. VogesProskauer and methyl red reactions are negative. Indole is not produced. $\mathrm{H}_{2} \mathrm{~S}$ is not produced. Nitrate is reduced to nitrite. Arginine dihydrolase, lysine decarboxylase and ornithine decarboxylase are absent. When assayed with the API ZYM system, alkaline phosphatase, esterase $\left(\mathrm{C}_{4}\right)$, esterase lipase $\left(\mathrm{C}_{8}\right)$, naphthol-AS-BI-phosphohydrolase and $\alpha$-glucosidase are present, but lipase $\left(\mathrm{C}_{14}\right)$, leucine arylamidase, valine arylamidase, cystine arylamidase, trypsin, $\alpha$-chymotrypsin, acid phosphatase, $\alpha$-galactosidase, $\beta$-glucuronidase, $\beta$-glucosidase, $\alpha$-mannosidase and $\alpha$ fucosidase are absent. $\beta$-Galactosidase and $N$-acetyl$\beta$-glucosaminidase are variable (positive for the type strain). Acid is produced from maltose, D-ribose and sucrose. Acid is not produced from L-arabinose, Dcellobiose, D-melezitose, D-raffinose, D-xylose, adonitol, $m y o$-inositol or D-sorbitol. Acid production from lactose is variable. The cell wall peptidoglycan contains mesodiaminopimelic acid. The predominant menaquinone is MK-7. The major fatty acids are anteiso- $\mathrm{C}_{15: 0}$ and anteiso$\mathrm{C}_{17: 0}$. The $\mathrm{G}+\mathrm{C}$ content is $38-39 \mathrm{~mol} \%$ (38 $\mathrm{mol} \%$ for the type strain).

The type strain, ATCC $49067^{\mathrm{T}}\left(=\mathrm{DSM} 10037^{\mathrm{T}}=\mathrm{LMG}\right.$ $9818^{\mathrm{T}}$ ), was isolated from a solar evaporation pond (saltern) in France. Further descriptive information for the type strain is given by Denariaz et al. (1989) and in Table 1.

\section{Acknowledgements}

This work was supported by the 21C Frontier program of Microbial Genomics and Applications (grant MG02-0401-001-1-0-0) and the NRL research program (grants M10104000294-01J000012800 and M10104000294-01J000012811) from the Ministry of Science and Technology (MOST) of the Republic of Korea.

\section{References}

Arahal, D. R., Márquez, M. C., Volcani, B. E., Schleifer, K. H. \& Ventosa, A. (1999). Bacillus marismortui sp. nov., a new moderately halophilic species from the Dead Sea. Int J Syst Bacteriol 49, 521-530.

Arahal, D. R., Márquez, M. C., Volcani, B. E., Schleifer, K. H. \& Ventosa, A. (2000). Reclassification of Bacillus marismortui as Salibacillus marismortui comb. nov. Int J Syst Evol Microbiol 50, 1501-1503.

Ash, C., Priest, F. G. \& Collins, M. D. (1993). Molecular identification of rRNA group 3 bacilli (Ash, Farrow, Wallbanks, and Collins) using a PCR probe test. Proposal for the creation of a new genus Paenibacillus. Antonie van Leeuwenhoek 64, 253-260. 
Baumann, P. \& Baumann, L. (1981). The marine Gram-negative eubacteria: genera Photobacterium, Beneckea, Alteromonas, Pseudomonas, and Alcaligenes. In The Prokaryotes, pp. 1302-1331. Edited by M. P. Starr, H. Stolp, H. G. Trüper, A. Balows \& H. G. Schlegel. Berlin: Springer.

Cohen-Bazire, G., Sistrom, W. R. \& Stanier, R. Y. (1957). Kinetic studies of pigment synthesis by nonsulfur purple bacteria. $J$ Cell Comp Physiol 49, 25-68.

Cowan, S. T. \& Steel, K. J. (1965). Manual for the Identification of Medical Bacteria. London: Cambridge University Press.

Denariaz, G., Payne, W. J. \& Gall, J. L. (1989). A halophilic denitrifier, Bacillus halodenitrificans sp. nov. Int J Syst Bacteriol 39, 145-151.

Ezaki, T., Hashimoto, Y. \& Yabuuchi, E. (1989). Fluorometric deoxyribonucleic acid-deoxyribonucleic acid hybridization in microdilution wells as an alternative to membrane filter hybridization in which radioisotopes are used to determine genetic relatedness among bacterial strains. Int J Syst Bacteriol 39, 224-229.

Heyndrickx, M., Lebbe, L., Kersters, K., De Vos, P., Forsyth, G. \& Logan, N. A. (1998). Virgibacillus: a new genus to accommodate Bacillus pantothenticus (Proom and Knight 1950). Emended description of Virgibacillus pantothenticus. Int J Syst Bacteriol 48, 99-106.

Heyndrickx, M., Lebbe, L., Kersters, K., Hoste, B., De Wachter, R., De Vos, P., Forsyth, G. \& Logan, N. A. (1999). Proposal of Virgibacillus proomii sp. nov. and emended description of Virgibacillus pantothenticus (Proom and Knight 1950) Heyndrickx et al. 1998. Int J Syst Bacteriol 49, 1083-1090.

Heyrman, J., Logan, N. A., Busse, H.-J., Balcaen, A., Lebbe, L., Rodriguez-Diaz, M., Swings, J. \& De Vos, P. (2003). Virgibacillus carmonensis sp. nov., Virgibacillus necropolis sp. nov. and Virgibacillus picturae sp. nov., three novel species isolated from deteriorated mural paintings, transfer of the species of the genus Salibacillus to Virgibacillus, as Virgibacillus marismortui comb. nov. and Virgibacillus salexigens comb. nov., and emended description of the genus Virgibacillus. Int J Syst Evol Microbiol 53, 501-511.

Komagata, K. \& Suzuki, K. (1987). Lipids and cell-wall analysis in bacterial systematics. Methods Microbiol 19, 161-203.

Lanyi, B. (1987). Classical and rapid identification methods for medically important bacteria. Methods Microbiol 19, 1-67.

Leifson, E. (1963). Determination of carbohydrate metabolism of marine bacteria. J Bacteriol 85, 1183-1184.

Lu, J., Nogi, Y. \& Takami, H. (2001). Oceanobacillus iheyensis gen. nov., sp. nov., a deep-sea extremely halotolerant and alkaliphilic species isolated from a depth of $1050 \mathrm{~m}$ on the Iheya Ridge. FEMS Microbiol Lett 205, 291-297.

Minnikin, D. E. O’Donnell A. G., Goodfellow, M., Alderson, G., Athalye, M., Schaal, A. \& Parlett, J. H. (1984). An integrated procedure for the extraction of bacterial isoprenoid quinones and polar lipids. J Microbiol Methods 2, 233-241.

Sasser, M. (1990). Identification of Bacteria by Gas Chromatography of Cellular Fatty Acids. Newark, DE: MIDI Inc.
Shida, O., Takagi, H., Kadowaki, K. \& Komagata, K. (1996). Proposal for two new genera, Brevibacillus gen. nov. and Aneurinibacillus gen. nov. Int J Syst Bacteriol 46, 939-946.

Spring, S., Ludwig, W., Marquez, M. C., Ventosa, A. \& Schleifer, K.-H. (1996). Halobacillus gen. nov., with description of Halobacillus litoralis sp. nov. and Halobacillus trueperi sp. nov., and transfer of Sporosarcina halophila to Halobacillus halophilus comb. nov. Int J Syst Bacteriol 46, 492-496.

Stackebrandt, E. \& Goebel, B. M. (1994). Taxonomic note: a place for DNA-DNA reassociation and 16S rRNA sequence analysis in the present species definition in bacteriology. Int J Syst Bacteriol 44, 846-849.

Staley, J. T. (1968). Prosthecomicrobium and Ancalomicrobium: new prosthecate freshwater bacteria. J Bacteriol 95, 1921-1942.

Tamaoka, J. \& Komagata, K. (1984). Determination of DNA base composition by reverse-phase high-performance liquid chromatography. FEMS Microbiol Lett 25, 125-128.

Wainø, M., Tindall, B. J., Schumann, P. \& Ingvorsen, K. (1999). Gracilibacillus gen. nov., with description of Gracilibacillus halotolerans gen. nov., sp. nov.; transfer of Bacillus dipsosauri to Gracilibacillus dipsosauri comb. nov., and Bacillus salexigens to the genus Salibacillus gen. nov., as Salibacillus salexigens comb. nov. Int J Syst Bacteriol 49, 821-831.

Wayne, L. G., Brenner, D. J., Colwell, R. R. \& 9 other authors (1987). Report of the ad hoc committee on reconciliation of approaches to bacterial systematics. Int J Syst Bacteriol 37, 463-464.

Wisotzkey, J. D., Jurtshuk, P., Jr, Fox, G. E., Deinhard, G. \& Poralla, K. (1992). Comparative sequence analysis on the $16 \mathrm{~S}$ rRNA (rDNA) of Bacillus acidocaldarius, Bacillus acidoterrestris, and Bacillus cycloheptanicus and proposal for creation of a new genus, Alicyclobacillus gen. nov. Int J Syst Bacteriol 42, 263-269.

Yoon, J.-H., Kim, H., Kim, S.-B., Kim, H.-J., Kim, W. Y., Lee, S. T., Goodfellow, M. \& Park, Y.-H. (1996). Identification of Saccharomonospora strains by the use of genomic DNA fragments and rRNA gene probes. Int J Syst Bacteriol 46, 502-505.

Yoon, J.-H., Lee, S. T. \& Park, Y.-H. (1998). Inter- and intraspecific phylogenetic analysis of the genus Nocardioides and related taxa based on 16S rDNA sequences. Int J Syst Bacteriol 48, 187-194.

Yoon, J.-H., Weiss, N., Lee, K.-C., Lee, I.-S., Kang, K. H. \& Park, Y.-H. (2001). Jeotgalibacillus alimentarius gen. nov., sp. nov., a novel bacterium isolated from jeotgal with L-lysine in the cell wall, and reclassification of Bacillus marinus Rüger 1983 as Marinibacillus marinus gen. nov., comb. nov. Int J Syst Evol Microbiol 51, 2087-2093.

Yoon, J.-H., Kang, K. H. \& Park, Y.-H. (2002). Lentibacillus salicampi gen. nov., sp. nov., a moderately halophilic bacterium isolated from a salt field in Korea. Int J Syst Evol Microbiol 52, 2043-2048.

Yoon, J.-H., Kim, I.-G., Kang, K. H., Oh, T.-K. \& Park, Y.-H. (2003). Bacillus marisflavi sp. nov. and Bacillus aquimaris sp. nov., isolated from sea water of a tidal flat of the Yellow Sea in Korea. Int J Syst Evol Microbiol 53, 1297-1303. 